\title{
KEPEDULIAN EKONOMI PERTANIAN
}

\section{PENDAHULUAN}

Pertanian dalam pengertian yang luas mencakup semua kegiatan yang melibatkan pemanfaatan makhluk hidup (termasuk tanaman, hewan, dan mikrobia) untuk kepentingan manusia. Dalam arti sempit, pertanian juga diartikan sebagai kegiatan pemanfaatan sebidang lahan untuk membudidayakan jenis tanaman tertentu, terutama yang bersifat semusim. Usaha pertanian diberi nama khusus untuk subjek usaha tani tertentu. Kehutanan adalah usaha tani dengan subjek tumbuhan (biasanya pohon) dan diusahakan pada lahan yang setengah liar atau liar (hutan). Peternakan menggunakan subjek hewan darat kering (khususnya semua vertebrata kecuali ikan dan amfibia) atau serangga (misalnya lebah). Perikanan memiliki subjek hewan perairan (termasuk amfibia dan semua non-vertebrata air). Suatu usaha pertanian dapat melibatkan berbagai subjek ini bersama-sama dengan alasan efisiensi dan peningkatan keuntungan.(Ali, 2014) Pertimbangan akan kelestarian lingkungan mengakibatkan aspek-aspek konservasi sumber daya alam juga menjadi bagian dalam usaha pertanian.

Semua usaha pertanian pada dasarnya adalah kegiatan ekonomi sehingga memerlukan dasar-dasar pengetahuan yang sama akan pengelolaan tempat usaha, pemilihan benih/bibit, metode budidaya, pengumpulan hasil, distribusi produk, pengolahan dan pengemasan produk, dan pemasaran. Apabila seorang petani memandang semua aspek ini dengan pertimbangan efisiensi untuk mencapai keuntungan maksimal maka ia melakukan pertanian intensif (intensive farming).(Hariyadi \& Purwanti, 2017) Usaha pertanian yang dipandang dengan cara ini dikenal sebagai agribisnis. Program dan kebijakan yang mengarahkan usaha pertanian ke cara pandang demikian dikenal sebagai intensifikasi. Karena pertanian industrial selalu menerapkan pertanian intensif,keduanya sering kali disamakan .Sisi yang berseberangan dengan pertanian industrial adalah pertanian berkelanjutan (sustainable agriculture) (LASTIANTI, 2015).

Pertanian berkelanjutan, dikenal juga dengan variasinya seperti pertanian organik atau permakultur, memasukkan aspek kelestarian daya dukung lahan maupun lingkungan dan pengetahuan lokal sebagai faktor penting dalam perhitungan efisiensinya. Akibatnya, pertanian berkelanjutan biasanya memberikan hasil yang lebih rendah daripada pertanian industrial.

\section{REFERENCES}

Ali, M. (2014). AGRIBISNIS "BEBEK SINJAY" DALAM PERSPEKTIF KEWIRAUSAHAAN DAN PEMASARAN.

Hariyadi, B. W., \& Purwanti, S. (2017). Application of IBA PGR Concentration On Germination of Sugarcane (SaccharumOfficinarum L) Cuttings. AGRICULTURAL SCIENCE, 1(1), 1-10.

LASTIANTI, S. D. D. (2015). KAJIAN MANAJEMEN RISIKO SEBAGAI UPAYA UNTUK MENCAPAI KEBERHASILAN PADA PROYEK KONSTRUKSI BAJA DAN SIPIL DI PT SUPRA SURYA INDONESIA. UNIVERSITAS AIRLANGGA. 